\title{
Searching for a nursing job in an increased complexity of the labour market: An integrative review of the literature
}

\author{
Giampiera Bulfone ${ }^{1}$, Roberta Fida ${ }^{2}$, Ercole Vellone ${ }^{1}$, Rosaria Alvaro $^{1}$, Alvisa Palese ${ }^{* 3}$ \\ ${ }^{1}$ Department of Biomedicine and Prevention, University of Rome "Tor Vergata", Rome, Italy \\ ${ }^{2}$ Norwich Business School, University of East Anglia, Norwich, United Kingdom \\ ${ }^{3}$ Department of Medical and Biological Science, University of Udine, Udine, Italy
}

Received: October 8, 2015

Accepted: November 1, 2015

Online Published: November 20, 2015

DOI: $10.5430 /$ jnep.v6n3p33

URL: http://dx.doi.org/10.5430/jnep.v6n3p33

\begin{abstract}
Introduction: Recently, the unemployment ratio for nurses at European level reached 9\% and an increased among nurses has been reported around the world. In several countries, such as Italy, searching for a nursing job has become a complex challenge. However, factors affecting the success in finding a nursing position have not received attention to date.

Methods: Aiming to synthesize the knowledge available on the process of searching for a job as a nurse, an integrative review of the literature was performed. A total of 419 articles were retrieved and 126 studies were eligible. Two researchers working independently have scrutinized the eligible articles. A total of 6 studies have been included and a content analysis was performed. Results: A content analysis of the studies was performed and the articles were categorized in accordance to the key findings in three themes: 1) voluntary and forced unemployment; 2) strategies adopted by nurses in searching for a job; and 3) factors influencing success in searching for a nursing job. Individual factors may play a great role in finding a nursing job in times of economic crisis. The lack of clinical preparedness and managerial competence perceived by newly graduated nurses may affect their success in searching for a nursing job.

Conclusions: Newly graduated should be prepared to face with the challenging process of finding a nursing job. Different policies have been suggested at individual, faculty and hospital levels.
\end{abstract}

Key Words: Nurse, New graduated nurse, Job application, Employment, Successful job search

\section{INTRODUCTION}

The economic crisis of 2008 in some European Union countries has led health services to pursue cost containment measures. ${ }^{[1]}$ Nurses' positions have been frozen or reduced, and due to revisions to retirement policies, the possibilities for the retirement of nurses have diminished therefore reducing the opportunity for new graduates to find employment. ${ }^{[2]}$ These factors have increased the unemployment ratios for nurses, ${ }^{[3]}$ which have become one of the most important issues in several countries resulting from an imbalance between the demand and supply of nurses. ${ }^{[4]}$

Various unemployment ratios for nurses have been documented around the world. ${ }^{[5]}$ In Canada the unemployment rate is around 7\%, in Colombia it has recently reached 39\%, in Korea 40.9\%, and in Mexico 43\%. ${ }^{[6]}$ In Kenya, South Africa, and Nigeria at least 30,000 unemployed nurses were documented around ten years ago; ${ }^{[7]}$ in India and in the Philippines, high unemployment rates have also been re-

\footnotetext{
*Correspondence: Alvisa Palese; Email: alvisa.palese@ uniud.it; Address: Department of Medical and Biological Science, University of Udine, Udine, Italy.
} 
ported among nurses. ${ }^{[8]}$ In Europe, the unemployed ratio has recently reached $9 \%^{[5]}$ and in Italy, it has been recently reported an unemployed ratio of $38 \%$ after one year of graduation. ${ }^{[9]}$

In several countries, searching for a nursing job has become a complex challenge ${ }^{[10]}$ and newly graduated nurses face many barriers to seeking a position. ${ }^{[1]}$ New graduates are required to develop competitive strategies to meet new job demands that require more experience, skills and a competitive orientation. ${ }^{[12]}$ When the entire process fails and prolonged unemployment occurs, competences and skills developed during nursing education may be threatened, and a sense of detachment to the nursing profession may be developed, then requiring more support during the transition from graduation to employment. ${ }^{[13]}$

However, the issue of factors affecting successful employment as a nurse, has not received attention to date, possibly due to different factors, such as: a) nursing shortages in some leading countries are still present, affecting therefore the likely possibility of finding the expected position; b) more attention given to the transition from student to registered nurse $;^{[14]}$ on the other hand, c) the amount of graduate nurses are limited in some countries, in accordance with the limited nursing educational opportunities, and also with the higher ratios of academic failure; and d) the labour market is more attracted to expert clinical nurses. Therefore, employment opportunities are not readily available for new graduates.

Summarizing the knowledge available on the process of searching for a job as a nurse, and on the individual factors that may positively affect the process, was the general intent of this integrative review.

\section{Searching for a nursing job as a new graduate}

In accordance with Brasher and Chen, the process of searching for a job is not well defined: having received a job offer and, thus, accepting a job placement, should be considered together with other factors. Job searching is a multidimensional construct and while predicting job search success, both individual and some situational variables should be considered. ${ }^{[15]}$

The job searching process for new graduates typically involves some steps: new graduates first generate a list of job alternatives, prepare for the job search process, then initiate the job search process (e.g., mailing resumes) and finally select a job from one or more offers that are received. ${ }^{[16]}$ The job search intensity measures the frequency of job search behaviour enacted during the process, while the job search effort describes the perceived investment of emotional energy in the job search process. ${ }^{[16]}$
Moynihan et al. ${ }^{[17]}$ have documented that the first phase in job searching is extensive (searching information among friends, family) and it is considered effective antecedent of job searching outcomes measured in increased number of job interviews, number of offers received and more likely to find a job. During the first phase the new graduate's exploration of the work environment ${ }^{[18]}$ and the ability to cope with the views of the recruiting employer may influence outcomes. ${ }^{[19]}$ Personal contacts are crucial in increasing the number of jobs placement opportunities rather than formal contacts. ${ }^{[20]}$

Individual factors seem to predict effectiveness in job searching. It was found that higher self-efficacy in job searching predicts effectiveness in preparatory, active and intense behaviours enacted in searching for a job, as well as the capability to activate informal resources, to manage a number of interviews, and success in finding a job. ${ }^{[21]}$ Several instruments of self-efficacy in finding a job have been validated (e.g., the Search for Work Self-Efficacy Scale by Avallone and Pepe). ${ }^{[21]}$ Self-efficacy also predicts the ability to fit with the job (Person-Job Fit, PJF) and with the organization's demands (Person-Organization Fit, POF) thus converting a job interview into an actual offer. ${ }^{[17]}$ A proactive personality has been also positively associated with job searching self-efficacy, considered as the confidence of a person with the ability of searching for a job and the number of work interviews performed and offers received. ${ }^{[22]}$

In addition to individual factors, contextual factors may also play a role. For new graduates migration to find a job is related to the advancement of professional opportunities, to a better quality work environment, to salary and the stability of the work position. ${ }^{[23]}$

Success in job finding is based on the evaluation of the initial salary, the degree of congruence between the position and the graduation achieved, the job position accepted and job quality because those under higher pressure are more likely to accept the first offer received. ${ }^{[24]}$

\section{METHODS}

An integrative review of the literature ${ }^{[25]}$ was performed. The following databases were accessed in July and August 2015: MedLine, CINAHL, Scopus, Business Source Complete, EconLit, TextLegal Collection, Regional Business News, DARE, Cochrane, NHS-EED. In accordance with the research question, the following strategies were performed:

- "Nurses" [Mesh] AND “job application" [Mesh] AND "employment" [Mesh];

- "New graduated nurses"[Mesh] AND ("job search" OR "job seeking”) (key word) AND "successful job search"(key word) AND "successful job seeking” (key

ISSN 1925-4040 E-ISSN 1925-4059 
word);

- "Nurses" [Mesh] AND “job application"[Mesh] AND "workplace employment" [Mesh];

- "New graduated nurses" [Mesh] AND (job search OR job seeking) (key word) AND "workplace employment" [Mesh].

- Using the same key words, grey literature through Google database was also searched. No limitations in time and language were applied.

A total of 419 articles were retrieved and, among these 139 were duplicates and therefore excluded. Among the remaining 280 articles, according to the evaluations made by two independent researchers who have scrutinised the titles and the abstracts, 123 articles were judged relevant to the research question. An ascendant and descendent searching of articles ${ }^{[26]}$ analysing the references reported and the citations obtained by each article as reported by the Scopus database was also performed. A total of three new articles were retrieved. Therefore, 126 studies were eligible.

Two researchers (GP, AP) have scrutinised the eligible articles independently, deciding their inclusion on the basis of the following criteria: 1) primarily studies including new nursing graduates or students at the point of their graduation, and 2) reporting empirical data using either qualitative or quantitative methodologies. Some 22 articles were eligible and only six were pertinent to the inclusion criteria above-mentioned.

In accordance with Whittemore, ${ }^{[27]}$ included studies were critically examined by two researchers (GP, AP), in an independent manner, in their aims, study design appropriateness, sampling and sample methods (inclusion and exclusion criteria, sample size, follow-up when appropriate), in the measured variables, as well as in the dropouts, and bias. Statistical analysis performed (when appropriate), findings presented, discussion and applicability of the results were also critically evaluated. A brief presentation of the methodological issues emerged through this critical evaluation has been reported within the results.

Therefore, a content analysis ${ }^{[26]}$ of the studies included was also performed by two researchers, in an independent fashion. Each article included ${ }^{[28-33]}$ was read and re-read in its full text aiming at capturing the main findings. In accordance to the main contents, three categories have emerged:

(1) Voluntary and forced unemployment: In this theme, those studies were included describing forced unemployment as those willing to work as a nurse, without having the possibility due to labour market reasons; and those voluntarily unemployed as those not searching for a nursing job due to personal reasons.
(2) Strategies adopted by nurses in searching for a job: As the interventions enacted by new graduates with the aim of finding a job as a nurse as documented by studies, and

(3) Factors influencing successfully the attainment of a position as a nurse: In this theme those studies were categorised that focused mainly on individual factors affecting success in nursing the search for a nursing job.

Given that studies were focused on multiple themes, each study was categorised according to the prevailing theme.

\section{Results}

\subsection{Methodological aspects of the studies emerged}

As reported in Table 1, the six articles retrieved were published from 2008 to 2012 based on data collected from 2003 and 2011. The studies were conducted in Brazil, Canada, Italy, Japan, Mexico, and USA. ${ }^{[2-33]}$ Four were based on quantitative study designs, ${ }^{[29-31,33]}$ one on qualitative study design $^{[28]}$ and one on mixed method. ${ }^{[32]}$ The majority of the quantitative studies were based on a retrospective design ( 3 out 4 ), followed by a cross-sectional study (1 out 4 ).

The studies included a sample ranging from 63 participants to 107,313 . While quantitative studies have involved a total sample of 108,328 participants ( $\min 63$, max 107,313), that based on qualitative design involved a total of 114 while the remaining mixed-method study involved 37 participants for the qualitative approach and 115 for the quantitative approach.

The age range of participants was from 18 to 65 , while regarding gender, the studies involved have reported higher percentages of females (from $80.4 \%$ to $100 \%$ ). The studies were developed mainly at the university level; in one case $\mathrm{e}^{[30]}$ employment agencies were also included, while in another ${ }^{[29]}$ the research process was conducted at the state level.

\subsection{Voluntary and forced unemployment}

From the findings that emerged, there is a proportion of forced unemployed nurses $(10.6 \%)^{[28]}$ represented as those nurses searching for a nursing job without success after two year of completing the nursing degree. Within this group, it is possible to also include those nurses employed in different roles such as nursing aides: $0.4 \%{ }^{[29]}$ and $12.5 \% .^{[28]}$ Moreover, there is also a proportion of voluntary unemployment including those new graduates who will continue to study $\left(26 \%,^{[31]} 1.4 \%{ }^{[29]}\right)$ or those who have the expectation to postpone their entry into a working position for personal reasons. ${ }^{[30]}$ 
Table 1. Themes of the studies included, and main characteristics

\begin{tabular}{|c|c|c|c|c|c|c|}
\hline \multirow{2}{*}{$\begin{array}{l}\text { Themes } \\
\text { Author(s) } \\
\text { and } \\
\text { Country(s) }\end{array}$} & \multirow{2}{*}{$\begin{array}{l}\begin{array}{l}\text { Voluntary or forced } \\
\text { unemployment }\end{array} \\
\text { Kawaguchi et al. } \\
2008^{[30]} \\
\text { Kyoto, Japan }\end{array}$} & \multicolumn{2}{|c|}{$\begin{array}{l}\text { Strategies adopted by nurses in the } \\
\text { process of searching for a job }\end{array}$} & \multicolumn{3}{|c|}{ Factors influencing success in searching for a nursing job } \\
\hline & & $\begin{array}{l}\text { Hirsch } 2011^{[29]} \\
\text { Washington, } \\
\text { USA }\end{array}$ & $\begin{array}{l}\text { Palese } \text { et al. } \\
2009^{[33]} \\
\text { Udine, Italy }\end{array}$ & $\begin{array}{l}\text { Colenci \& Bereti } \\
2012^{[28]} \\
\text { S. Paolo, Brasil }\end{array}$ & $\begin{array}{l}\text { Freeman et al. 2012 } \\
\text { Windsor, Canada }\end{array}$ & $\begin{array}{l}\text { Martinez et al. } \\
2010^{[31]} \text { Mexico }\end{array}$ \\
\hline $\begin{array}{l}\text { Primary } \\
\text { purpose of } \\
\text { the study }\end{array}$ & $\begin{array}{l}\text { To examine inactive } \\
\text { nurses' job-searching } \\
\text { behaviours to return to } \\
\text { workplace where } \\
\text { serious difficulty of } \\
\text { meeting demand and } \\
\text { supply of nurses } \\
\text { exists. }\end{array}$ & $\begin{array}{l}\text { To examine the } \\
\text { employment } \\
\text { status of the } \\
\text { newly licensed } \\
\text { nurses. }\end{array}$ & $\begin{array}{l}\text { To describe } \\
\text { factors } \\
\text { influencing the } \\
\text { first choice of } \\
\text { employment in a } \\
\text { public sector. }\end{array}$ & $\begin{array}{l}\text { To analyse the } \\
\text { graduates' } \\
\text { perceptions } \\
\text { regarding their } \\
\text { development } \\
\text { process, focusing } \\
\text { on the conditions of } \\
\text { entering the job } \\
\text { market and the } \\
\text { demands they deal } \\
\text { with in their } \\
\text { professional life. }\end{array}$ & $\begin{array}{l}\text { To explore the migration } \\
\text { intentions of graduates and } \\
\text { the factors influencing their } \\
\text { decision-making. }\end{array}$ & $\begin{array}{l}\text { To analyse the } \\
\text { factors } \\
\text { associated with } \\
\text { the } \\
\text { expectations to } \\
\text { migrate abroad } \\
\text { among nursing } \\
\text { students. }\end{array}$ \\
\hline $\begin{array}{l}\text { Study } \\
\text { design, } \\
\text { data } \\
\text { collection } \\
\text { baseline }\end{array}$ & $\begin{array}{l}\text { Study Design }=\text { R } \\
\text { Baseline }=\text { 2004-2005 }\end{array}$ & $\begin{array}{l}\text { Study Design = R } \\
\text { Baseline = 2009- } \\
2010\end{array}$ & $\begin{array}{l}\text { Study Design = R } \\
\text { Baseline = 2003- } \\
2004\end{array}$ & $\begin{array}{l}\text { Study Design = } \\
\text { CSD } \\
\text { Baseline }=2007\end{array}$ & $\begin{array}{l}\text { Study Design = MM } \\
\text { Explanatory sequential } \\
\text { Baseline = } 2011\end{array}$ & $\begin{array}{l}\text { Study Design = } \\
\text { CS } \\
\text { Baseline }= \\
2007\end{array}$ \\
\hline Participants & $\begin{array}{l}\text { Unemployed, } \\
\text { registered in Nursing } \\
\text { Association Computer } \\
\text { System } \\
\mathrm{N}=107,313 \\
\text { Age }=18-24 \text {; } \\
\text { Female }=100 \%\end{array}$ & $\begin{array}{l}\text { Washington State } \\
\text { Newly licensed } \\
\text { nurses } \\
\mathrm{N}=532 \\
\text { Age = 21-65; } \\
\text { Female = NR }\end{array}$ & $\begin{array}{l}\text { University of } \\
\text { Udine } \\
\text { New graduates } \\
\mathrm{N}=63 \\
\text { Age }=24( \pm 2.9) ; \\
\text { Female }=91.1 \%\end{array}$ & $\begin{array}{l}\text { Faculda de } \\
\text { Marachal Rondon } \\
\text { New graduates } \\
\mathrm{N}=114 \\
\text { Age }=32.7 \% \\
(26-30) ; \text { Female = } \\
85.6 \%\end{array}$ & $\begin{array}{l}\text { Canadian University } \\
\text { New graduates } \\
\text { N = } 152 \text { (115 QN; } 37 \text { QL) } \\
\text { Age = } 23(21-53) ; \\
\text { Female = 80.4\% QN; 15.3\% } \\
\text { QL }\end{array}$ & $\begin{array}{l}\text { Mexico City } \\
\text { University } \\
\text { Students } \\
\mathrm{N}=420 \\
\text { Age }=20-24 ; \\
\text { Female = } \\
85.6 \%\end{array}$ \\
\hline $\begin{array}{l}\text { Variables } \\
\text { under study }\end{array}$ & $\begin{array}{l}\text { Work experience, } \\
\text { duration of } \\
\text { employment and } \\
\text { reasons for leave the } \\
\text { job; qualification and } \\
\text { number of preschool } \\
\text { children; desired } \\
\text { institution, department } \\
\text { and employment status } \\
\text { (part time or full time); } \\
\text { working profile (day } \\
\text { shift only, night shift } \\
\text { only or rotating shift) }\end{array}$ & $\begin{array}{l}\text { Finding first job } \\
\text { (e.g., strategies } \\
\text { adopted, number } \\
\text { of applications) } \\
\text { and job } \\
\text { satisfaction }\end{array}$ & $\begin{array}{l}\text { Number of } \\
\text { applications } \\
\text { submitted; } \\
\text { number of } \\
\text { interviews } \\
\text { performed; } \\
\text { number of offers } \\
\text { received; factors } \\
\text { influencing the } \\
\text { selection of the } \\
\text { best offer to } \\
\text { consider }\end{array}$ & $\begin{array}{l}\text { Perceptions about } \\
\text { the professional } \\
\text { education received; } \\
\text { difficulties in } \\
\text { getting the first job }\end{array}$ & $\begin{array}{l}\text { Factors influencing } \\
\text { migration (economic reward, } \\
\text { professional development, } \\
\text { healthy work environment, } \\
\text { safe living and work } \\
\text { environment, opportunity for } \\
\text { adventure, autonomy in } \\
\text { choice of workplace, social } \\
\text { support and support in ethical } \\
\text { practice) }\end{array}$ & $\begin{array}{l}\text { Marital status; } \\
\text { father's } \\
\text { education level; } \\
\text { income in the } \\
\text { family; } \\
\text { relatives in } \\
\text { foreign } \\
\text { countries }\end{array}$ \\
\hline $\begin{array}{l}\text { Key } \\
\text { findings }\end{array}$ & $\begin{array}{l}\text { Having preschool } \\
\text { children is one of the } \\
\text { factors that delays } \\
\text { finding a job and } \\
\text { failing to obtain } \\
\text { desired workplace and } \\
\text { working profile; } \\
\text { nurses with higher } \\
\text { educational } \\
\text { backgrounds tend to } \\
\text { spend longer finding } \\
\text { jobs. }\end{array}$ & $\begin{array}{l}\text { Nearly } 81 \% \\
\text { reported to be } \\
\text { hired as a nurse, } \\
\text { and } 69.5 \% \text { were } \\
\text { very or somewhat } \\
\text { satisfied with } \\
\text { their employment } \\
\text { situation. New } \\
\text { graduates apply } \\
\text { for several } \\
\text { positions in } \\
\text { different } \\
\text { institutions in a } \\
\text { market that do not } \\
\text { allow for job or } \\
\text { position choice. } \\
\text { For those } \\
\text { dissatisfied, the } \\
\text { position they } \\
\text { accepted was a } \\
\text { compromise } \\
\text { between the } \\
\text { necessity to work } \\
\text { and the } \\
\text { expectation. }\end{array}$ & $\begin{array}{l}\text { The new } \\
\text { graduates } \\
\text { presented } 101 \\
\text { applications and } \\
\text { had } 77 \\
\text { interviews; the } \\
\text { choice of hospital } \\
\text { depended on the } \\
\text { initial interview } \\
\text { with the nursing } \\
\text { directors and the } \\
\text { following } \\
\text { variables: the } \\
\text { availability of } \\
\text { places in the } \\
\text { requested ward; } \\
\text { the kind of } \\
\text { patients } \\
\text { admitted; the } \\
\text { possibility to } \\
\text { apply the nursing } \\
\text { knowledge, and } \\
\text { the desire for } \\
\text { professional } \\
\text { advancement. }\end{array}$ & $\begin{array}{l}\text { The lack of } \\
\text { preparedness in } \\
\text { clinical training, } \\
\text { market competition, } \\
\text { as well as the few } \\
\text { nursing positions } \\
\text { available in the } \\
\text { region, were the } \\
\text { main obstacles in } \\
\text { finding a job as a } \\
\text { nurse. More } \\
\text { managerial } \\
\text { competencies are } \\
\text { required by newly } \\
\text { graduates. }\end{array}$ & $\begin{array}{l}\text { The majority of the } \\
\text { participants (86\%) preferred } \\
\text { to work in Canada. However, } \\
\text { those willing to work in the } \\
\text { USA, were } 66.1 \% \text {. Knowing } \\
\text { a nurse who worked in the } \\
\text { US and living in a border } \\
\text { community were predictors } \\
\text { of migration. Those intended } \\
\text { to migrate have reported } \\
\text { significantly higher } \\
\text { expectations regarding } \\
\text { economic, professional } \\
\text { development, healthy work } \\
\text { environment, adventure and } \\
\text { autonomy values, and } \\
\text { believed that these would be } \\
\text { met in a country other than } \\
\text { Canada. Clinical instructors } \\
\text { and experiences play a } \\
\text { significant role in framing } \\
\text { students' perceptions of the } \\
\text { work environment, } \\
\text { influencing their choice of } \\
\text { specialty and where they } \\
\text { searched for their first job. }\end{array}$ & $\begin{array}{l}\text { A total of } 69 \% \\
\text { of the } \\
\text { informants } \\
\text { expressed their } \\
\text { intention to } \\
\text { search for a job } \\
\text { abroad, in } \\
\text { Canada, } \\
\text { followed by } \\
\text { Spain and the } \\
\text { USA. Variables } \\
\text { predicting } \\
\text { migration } \\
\text { expectations } \\
\text { were, among } \\
\text { other, income, } \\
\text { and the } \\
\text { perception of } \\
\text { poor labour } \\
\text { conditions and } \\
\text { low wages in } \\
\text { Mexico. }\end{array}$ \\
\hline
\end{tabular}


A large study conducted on a sample of 107,313 Japanese female nurses, those with pre-school children had a longer period of job search and for them it was harder to find a job than women without children. Kawaguchi et al. ${ }^{[30]}$ have shown that a period without working of more than two years has a negative correlation with the probability of finding a job and, at the least, a long term working break may decrease job-seekers' skill levels. However, the same study showed that Japanese female nurses with higher academic backgrounds had a higher probability of finding a job in their desired workplace. This was voluntary unemployment because the nurses with higher academic education spend more time in job searching until they have obtained the position desired. ${ }^{[30]}$

\subsection{Strategies adopted by nurses in searching for a job}

Hirsch, ${ }^{[29]}$ in order to evaluate the employment status of nurses in Washington State (USA), from 2009 to 2010 administered a questionnaire to a sample of 532 nurses. At the time of the questionnaire, around $80.8 \%$ were employed as a nurse, $15.1 \%$ were looking for a nursing job, and $0.4 \%$ were already working but not as a nurse. A few participants $(1.4 \%)$ were unemployed and were not looking for a job as a nurse. The participants reported having used several strategies to find a job (web $=87.7 \%$, personal contacts $=$ $72.1 \%$; newspaper advertisements $=42.3 \%$; telephone contacts $=36.2 \%)$. Among the participants, a large number (47\%) had applied for more than eight jobs, and more than a quarter $(28.2 \%)$ for one or two jobs. After having applied, the majority $(64.3 \%)$ had attended one or two interviews, but more than a quarter $(26.7 \%)$ had attended from three to five interviews. A large number of participants (70.5\%) had received at least one job offer, and a quarter (26\%) from two to three offers. The time elapsed from the beginning to the end of the job searching process lasted less than three months $(58.7 \%)$ to four and six months $(20.5 \%)$. The factors that were taken into consideration in the decision to accept a job offer were mainly related to the place of work $(55.6 \%)$, the reputation of the employer $(49.4 \%)$, the possibility of a period of internship/preceptorship (39.1\%). However, 34.1\% of participants reported that there were no factors affecting the decision given that they had received only one offer.

Palese et $a l .^{[33]}$ showed the strategies adopted by Italian new graduates in the public sector, which are recruited on the basis of public selection. Candidates have to formally submit their curriculum as employment applications. In accordance with the findings, new graduates made on average 2.2 (Standard Deviation $[ \pm]$ 1.06) employment applications and attended on average $1.7( \pm 0.6)$ interviews. The decision to accept a job offer was based mainly on the possibility to

Published by Sciedu Press choose the ward on which to start working as a nurse (23; $56.1 \%$ ), and the abilities of the recruiting nursing manager who conducted the interview $(14 ; 43.1 \%)$.

\subsection{Factors influencing success in finding a nursing job}

Colenci and Berti ${ }^{[28]}$ interviewed three groups of new graduates with the aim of analysing the perceptions that they have with regard to their education in view of the conditions for entering the job market. The first group was working as a nurse $(55.8 \%)$, the second as nursing aides while the third as nursing technicians $(12.5 \%$ and $5.7 \%)$. The remaining new graduates were not working as a nurse due to unemployment $(10.6 \%)$ or due to employment in a role outside nursing $(14.4 \%)$. Each group expressed a lot of difficulties regarding the job search, because during nursing education, both theory and clinical internship experiences were below expectations and very poor. The clinical internship was repetitive and the nursing activities, especially those requiring higher competences such as enteral catheterization or blood gas analysis, were never experienced and achieved. Therefore, the lack of clinical preparedness and managerial competences was considered to affect the ability to find a job as a nurse in the competitive labour market. New graduates reported that the recruitment processes attracted a large number of nurses with several years of experience who had more skills compared to them. ${ }^{[28]}$

Success in searching for a job is also influenced by the labour conditions both of the donor and receiving country in the case of migrant nurses. Freeman et al. ${ }^{[32]}$ have explored the migration intention of those newly graduated in nursing and the factors influencing their decision-making. Those with the intention to migrate $(66.1 \%)$ reported significantly higher expectations in their own economic and professional development, professional autonomy and personal safety, as well as expecting a healthy work environment. Migration was related to the quality of care offered to patients, as well as the economic pressures and the possibility of being engaged in particular professional fields. Decision making about migration was also influenced by other factors such as clinical experiences and clinical instructors who may influence the new graduate's first clinical choice where they have secured their first job. Knowing a nurse who lives abroad and living in a border community are strong predictors of searching for a nursing job abroad. ${ }^{[32]}$

Also Martinez and colleagues ${ }^{[31]}$ reported that $69 \%$ of nursing students had the intention to move abroad for job seeking $(65 \%)$ and/or to continue their studies $(26 \%)$. The variables associated with the intention to migrate were among others (e.g., having relatives abroad, $<24$ years old), the limited income, the limited possibilities for professional development 
and the perception of poor labour conditions in their own country.

\section{Discussion}

\subsection{Methodological issues}

Only six studies have emerged. The majority of them were conducted before the economic crisis affecting the Western world. ${ }^{[34]}$ Studies have described the phenomenon mainly for women thus reflecting a possible gender bias in the findings, ${ }^{[26]}$ although most nurses are female. The retrieved studies involved mainly newly graduated nurses, with a wide age range, from young new graduates (18 years $\left.{ }^{[30]}\right)$ to mature (from 26 to $30^{[28]}$ ), up to $65,{ }^{[29]}$ thus reflecting different job expectations and job searching capabilities. The studies did not compare the job searching process and outcomes between new nursing graduates and those graduates in other health-care fields which may have different job opportunities.

The emerged studies are sparse, involving individual countries which may have reflected the particular conditions of the labour market; no longitudinal study design has emerged which should be considered the most appropriate design in this field in accordance with the need to discover the factors affecting the process which may change over time. Studies based on prolonged follow-up periods are suggested in accordance with the increased length of unemployment reported in some countries. ${ }^{[13]}$

The studies were conducted mainly by the universities, indicating that faculty members are concerned regarding the future of their new graduates; only one study ${ }^{[30]}$ has involved government bodies overseeing employment issues. Employability $^{[35]}$ is not just the problem of the newly graduated individual or the Higher Education Institutions (HEIs) but should also be an issue for employers. Often, however, the employability clashes with the different expectations of the actors involved: HEIs and employer expectations are focused on different missions, to develop competences in a specific discipline, and having workers capable of acting effectively in complex environments, respectively. The expectations of HEIs and those of the employers should be aligned to help new graduates to design their careers effectively without having to undergo exhaustive job searches. ${ }^{[11]}$ Therefore, in future research, given that the transition from graduation to employment affects both universities and the world of work, cooperative studies are suggested.

The time lag from the data collection process to publication varies up to a maximum of five years $;^{[28,33]}$ in addition, some data were missing in studies, such as the gender of participants, ${ }^{[29]}$ thus suggesting more rigorous studies including all information for enabling a critical assessment of the external validity $^{[26]}$ of findings over the years.

\subsection{Barriers to find a nursing job: the concept of volun- tary and forced unemployment}

New graduates desire to find a job as a nurse in a short time, but some of them postpone their job search for personal reasons. ${ }^{[28-30]}$ Thus, from the findings, in addition to a forced, involuntary-based unemployment period while new graduates are trying to find the expected nursing position, there is also a voluntary-based unemployment period due mainly to individual factors such as family commitments.

These different unemployment conditions, due to different reasons, may reflect the difficult labour conditions, as well as new graduates' unpreparedness to deal with the complexity of the labour conditions but also personal needs. ${ }^{[36]}$ For Tomlinson $^{[36]}$ there are at least three possible profiles with regard to job searching: a) refugees who demonstrate periodical work-detachment, abandoning the job or preferring temporary solutions; they feel unprepared and prefer to plan work commitments on a temporary basis, assuring pauses for personal freedom and needs; b) ritualists are those demonstrating less emotional involvement, they are interested in relative economic security rather than professional development; in addition, they are not attracted by competition and they may accept jobs outside nursing; and c) careerists are those demonstrating strong orientation to work and to career development; they are committed and determined to achieve the desired career as a nurse.

With the time elapsing due to forced unemployment, new graduates may reduce their expectations and accept different jobs or lower positions. ${ }^{[11]}$ Accepting different or lower positions (e.g., as nursing aides) ${ }^{[28]}$ could become frustrating for the individual, and expensive for countries that have invested in nursing education, and a waste because the valuable competences for the health of its citizens are not exploited. Also for those who are voluntarily unemployed, postponing the entrance into work may affect competences and attachment to the profession. ${ }^{[37]}$ Further studies should differentiate between voluntary and forced unemployment as well as the proportion of those accepting a compromise, thus working in different or lower positions, while awaiting a nursing job.

\subsection{Strategies adopted by nurses in searching for a job}

Searching for a job is a process that involves informal and formal strategies: the informal networks reflect the relationship of the newly graduated with a range of resources (e.g., personal contacts) able to facilitate the finding of a job, while formal strategies are represented by classic channels (e.g., list of job positions published by hospitals). In other fields, such as Humanities, Social and Natural Sciences, Law, Engi- 
neering and Management new graduates with a number of informal contacts appear to be more effective in searching for a job but not necessarily able to find the expected position when starting out. ${ }^{[20]}$

In accordance with the numbers of attempts reported by available studies, ${ }^{[29,33]}$ searching for a job seems to be complex and expensive: requires tenacity on the part of the newly graduated, and above all, requires employers to have a need for new graduates. In times of economic crisis new graduates probably intensify their efforts, the duration of their job search is longer up to six or more months ${ }^{[29]}$ but the willingness of employers is very limited. In this scenario, the acceptance of a job offer may involve a compromise (e.g., accepting a role as a nursing aide); possibly, the process of searching for a job may also occur in a different manner due to scarce job opportunities and high competition. In this context, new graduates with less informal contacts may have more difficulties compared with those equipped with several networks; helping undergraduates to develop effective relations during their education with clinical tutors and nursing leaders at the hospitals attended, could help them gain a first reference network on which to move while searching for a job.

Searching for a job is a process, starting with a preparatory phase and proceeding to a more active and intense phase, in which people explore, measure themselves, and change over time the strategies adopted to achieve the outcomes. ${ }^{[38]}$

Therefore searching for a job is itself a learning process, probably never experienced before in its complexity by new nursing graduates. According to the self-regulation theory, interacting with the environment, new graduates receive feedbacks with regard to the behaviours adopted which they may self-regulate in accordance with the feedbacks received. However, different self-regulatory mechanisms of thought, emotions and behaviours have been reported among job seekers: ${ }^{[39]}$ those new graduates with a focus on promotion are sensitive to success and use energy to achieve their purpose of finding a job; those with a focus on prevention are sensitive to defeat and therefore they mainly activate energy to protect themselves. Nurse educators have many opportunities to identify those students who are not proactive or with low self-efficacy; as well as those not learning when feedbacks are offered or those with a preventive focus: many strategies should be undertaken for these students especially in order to enhance these abilities. These strategies should draw on studies that test in the field of nursing education, strategies and their effectiveness to help students in developing proactive, self-efficacy, able to learn through feedback, and with a promotion focus.
In accordance with the definition given by Brasher and Chen, ${ }^{[15]}$ the process of searching for a job should be considered together with other factors such as the job search duration, the job quality, the initial salary, and the degree of congruence between the academic field studied and the job position accepted. Current literature available in the nursing field is more focused on the process of searching for a job regardless of its outcomes; therefore, more studies are needed.

\subsection{Factors influencing success in finding a nursing job}

In contrast to the findings of McKeown and Lindforff, ${ }^{[11]}$ new nursing graduates do not underestimate the competitiveness of the labour market. ${ }^{[28]}$ However, the lack of clinical preparedness and managerial competences, which are essential to the process of job searching, may affect success in searching for a nursing job. Some HEIs coach students in developing personal strategies aimed at increasing their employability including specific seminars within the curriculum, while other HEIs work in partnership with potential employers. However, some universities still think that employers and HEIs have two different and inconceivable missions: teaching and researching for universities vs. developing services, products and business for employers. ${ }^{[35]}$ In nursing education, clinical placements represent a great opportunity in which HEIs and health care institutions may align their mission and expectations helping new graduates to be prepared for the competition to find a job. ${ }^{[28]}$ Universities should prepare the next generations to be able to face the challenges of the labour market, building a partnership with representatives and stakeholders of the working world, and the recruitment process must take into account the possibility for the new graduate to express choice about the clinical ward. Offering simulations, videos, supervised activities may increase the preparedness of the new graduates and their capability to perform an effective self-presentation in a resume or in an interview; ${ }^{[40]}$ these strategies may also increase proactivity ${ }^{[41]}$ and motivation ${ }^{[42,43]}$ as documented by a meta-analysis focused on job search interventions. ${ }^{[44]}$

In addition to the individual factors affecting the ability to deal with the complexity of the labour market, some contextual conditions such as the safety of the health care environments, the security perceived, the salary and the possibility for professional and career developments, may determine the decision to leave one's own country in favour of searching for a job abroad. ${ }^{[31,32]}$ With the growth of countries suffering from recession in which the supply model of nurses is unaligned, ${ }^{[4,5]}$ and where the amount of nurses graduating every year is appropriate to the needs of the country but the chances of employing them are really limited, ${ }^{[5]}$ the decision 
to remain in the country or to leave is largely based upon which global players offer a job opportunity first. ${ }^{[15]}$ Finding a job in a country that does not have enough nurses and where the economic conditions are better is easier: takes fewer interviews and fewer applications if the language is acknowledged.

\subsection{Limitations}

There are several limitations of this integrative review: studies involving a mix of populations (new graduates, students) with different study designs, in different countries and over 14 years, were included with the aim of gaining a comprehensive view of the studies available in the field. The reasons for nursing migration were not explored in depth in accordance with the main aim of the study which was to understand the individual factors affecting the job search as a nurse. The external validity of the findings that emerged is affected by economic and labour market conditions, as well as by changes in working conditions, rules and constraints that have emerged in several countries in recent years. Therefore, there is a need to continue to develop research in this field aimed at updating the evidence produced in different economic and labour market conditions. In addition, nursing researchers should address the lack of knowledge that has emerged to develop a more solid body of knowledge to be able to take more evidence-based approaches in the future introducing students to their first job search and effectively planning their career.

\section{CONCLUSIONS AND IMPLICATIONS FOR LABOR POLICIES}

Searching for a job as a nurse in some countries has become difficult: some patients receive limited nursing care when they have need for much more, but the economic conditions of these countries require significant staff reductions. Therefore, paradoxically, searching for a nursing job in countries where an increased nursing shortage is documented may become difficult and intensely competitive. In the attempt to find a job, new graduates may accept lower positions with roles below their professional education; in addition, hospitals facing critical staff conditions may be more attracted to competent nurses than those recently graduated. With the increased time elapsing from graduation to employment, the competences of the new graduates may decline, determining increased difficulties in finding a nursing position. Understanding the strategies adopted by new graduates to face a difficult job market and to avoid involuntary unemployment has become urgent for faculty members, nursing leaders and hospitals.

Few studies to date have developed knowledge in the field of searching for a nursing job. Studies emerged are sparse, performed before the current economic crisis, conducted in different labour market conditions, and mainly descriptive in nature. The studies have reported the process enacted by new graduates in searching for a nursing job, and the factors influencing their success, without taking into consideration the personality traits of the nurses which may influence the strategies adopted and the achievement of the expected nursing position. In addition, the outcomes of the searching process for a nursing job such as the initial salary, the quality of the initial position, its duration, and the degree of congruence between the position obtained and the graduation achieved need to be documented in further studies.

From the prospective of the new graduates, there is a need to increase their competiveness and their ability to face a complex labour market changes. New graduates should be prepared to deal with the challenging process of finding a job. During nursing education, HEIs should design and offer courses focused on job searching skills where students may be oriented to the most effective strategies, as well as how to prepare a curriculum vitae and effectively manage a job interview. New graduates should be involved in clinical training also after graduation, aiming at maintaining competences: therefore, continuing educational strategies, mainly compulsory required and offered at the theoretical level in several countries, should also include clinical training opportunities.

Faculties and health care institutions may also effectively align their mission regarding how to better prepare nursing students and how to help them in developing professional networks before completing their nursing programmes. In addition, hospitals should reserve positions for new graduates and draw up a mentoring initiative for their professional development and transition from newly graduate competences to more expert levels. These positions or training opportunities, such as opening the skill lab centres for free to graduates, should be considered as a strategy for continuing education. A partnership between career centres, employers and HEIs for discussing different expectations with regard to initial competences of new graduates and their need of preceptorship are suggested.

\section{CONFlicts of InTERest Disclosure}

The authors declare there are no competing interests. 


\section{REFERENCES}

[1] Mckee M, Kananikolos M, Belcher P, et al. Austerity: A failed experiment on the people of Europe. Clin Med. 2012; 12(4): 346-50. http://dx.doi.org/10.7861/clinmedicine.12-4-346

[2] European Federation of Nurses (EFN). Caring in crisis: The impact of the financial crisis on nursing and nurses. 2012.

[3] Vaughan-Whitehead D. Work inequalities in the crisis: Evidence from Europe. Geneva, Switzerland: International Labour Market; 2012.

[4] International Center for Human Resources in Nursing (ICHRN). Unemployment and Underemployment Nurses. International Council of Nurses. 2011.

[5] Wray J. The impact of the financial crisis on nurses and nursing. J Adv Nurs. 2013; 69(3): 497-499. http://dx.doi.org/10.1111 /jan. 12031

[6] Internal Council of Nurses (ICN). Nursing workforce profile database summary. 2013.

[7] Oulton J. The Global Nursing Shortage. Building Global Alliance III Conference. Philadelphia, USA; 2013.

[8] Alonso-Garbayo A, Maben J. Internationally recruited nurses from India and the Philippines in the United Kingdom: The decision to emigrate. Hum Resour Health. 2009; 7: 37-47. http: //dx.doi .o $\mathrm{rg} / 10.1186 / 1478-4491-7-37$

[9] Almalaurea. Condizione Occupazione dei laureati. Available from: https://www.almalaurea.it/universita/occupazione

[10] Nunley JM, Pugh A, Romero N, et al. Unemployment, underemployment, and employment opportunities: results from a correspondence audit of the labour market for college graduates. Auburn; University Department of Economics Working Paper Series; 2014.

[11] McKeown T, Lindforff M. The graduate job search process - A lesson in persistence rather than good career management?. Education + Training. 2011; 53(4): 310-20. http://dx .doi .org/10.1108/0 0400911111138479

[12] Perrone L, Vickers M. Life after graduation as a very uncomfortable world: An Australian case study. Education + Training. 2003; 45(2): 69-78. http://dx.doi.org/10.1108/00400910310464044

[13] Spetz J. Unemployed and Underemployed Nurses. Geneva, Switzerland; ICN - International Council of Nurses. 2011.

[14] Kumaran S, Carney M. Role transition from student nurse to staff nurse: Facilitating the transition period. Nurse Educ Pract. 2014; 14(6): 605-11. http://dx.doi.org/10.1016/j.nepr.2014.0 6.002

[15] Brasher EE, Chen PY. Evaluation of success criteria in job search: A process perspective. J Occup Organ Psychol. 1999; 72: 57-70. http://dx.doi.org/10.1348/096317999166491

[16] Hausdorf P. Job Search Outcomes for University Graduates: The Role of Economic Hardship and Work Involvement. Canadian Journal of Career Development/Revue Canadienne de Development de Carriere. 2007; 6(1): 22-8.

[17] Moynihan LM, Roehilin MV, Lepine MA, et al. A longitudinal study of the relationship among job search self-efficacy, job interviews and employment outcomes. J Bus Psychol. 2003; 18(2): 207-32. http://dx.doi.org/10.1023/A:1027349115277

[18] Werbel DJ. Relationship among career exploration, job search intensity, and job search effectiveness in graduating college students. J Vocat Behav. 2000; 57: 379-94. http://dx.doi.org/10.1006/j vbe. 2000.1746

[19] Higgins CA, Judge TA. The effect of applicant influence tactics on recruiter perceptions of fit and hiring recommendations: A field study. J Appl Psychol. 2004; 89(4): 622-32. http://dx.doi .org/10.10 37/0021-9010.89.4.622
[20] Obukhova E. Motivation VS. Relevance: Using strong ties to find a job in Urban China. Soc Sci Res. 2012; 41: 570-80. http: //dx.doi.org/10.1016/j.ssresearch.2011.12.010

[21] Saks AM. Multiple predictors and criteria of job search success. J Vocat Behav. 2006; 68: 400-15. http://dx.doi.org/10.1016/j .jvb.2005.10.001

[22] Brown JD, Cober K, Levy PE, et al. Proactive personality and the successful job search: A field investigation with college graduates. J Appl Psychol. 2006; 91(3): 717-26. http://dx .doi.org/10.10 37/0021-9010.91.3.717

[23] Braswell CM, Gottesman RW. Analysis of factors influencing employment migration of recent degree recipient. Annual Forum of the Association for Institutional Research. 2001.

[24] Granovetter M. Getting a job: A study of contacts and career Chicago; University of Chicago Press; 1995

[25] Cooper HM. Scientific guidelines for conducting integrative reviews Rev Ed Res. 1982; 52(2): 291-302. http://dx.doi.org/10.31 $02 / 00346543052002291$

[26] Polit DF, Tatano-Beck C. Fondamenti di ricerca Infermieristica. Milano, Italy: McGraw Hill Education; 2014

[27] Whittemore R. Combining evidence in nursing research: Methods and implications. Nurs Res. 2005; 54(1): 56-62. http://dx.doi.o rg/10.1097/00006199-200501000-00008

[28] Colenci R, Berti EW. Professional development and entering the labour market: the perceptions of nursing graduates. Revista Escola Enfermeria USP. 2012; 46(1): 153-61.

[29] Hirsch A. Report of survey results for newly licensed registered nurses in Washington State. J Nurs Educ. 2011; 50(10): 575-78 http://dx.doi.org/10.3928/01484834-20110616-01

[30] Kawaguchi A, Yasukawa F, Matsuda Y. An analysis job search behaviour of inactive nurses in Japan. J Clin Nurs. 2008; 7: 3275-85. http://dx.doi.org/10.1111/j.1365-2702.2008.02655.x

[31] Martinez YR, Nigenda G, Galárraga O, et al. Migration expectations among nursing students in Mexico City. Salud Pública Méx. 2010; 52(3): 244-53.

[32] Freeman M, Baumann A, Akhtar-Danesh N, et al. Employment goals, expectations, and migration intentions of nursing graduates in a Canadian border city: a mixed method study. Int J Nurs Stud. 2012; 49: 1531-43. http://dx.doi.org/10.1016/j.ijnurstu. 2012 .07 .015

[33] Palese A, Tosatto D, Mesaglio M. Process and factors influencing Italian nurse graduates' first choice of employment: A descriptive study. J Nurses Staff Dev. 2009; 25(4): 184-90. http: //dx.doi.org/10.1097/NND.0b013e3181ae13e2

[34] Doetter LF, Gotze R. Health policy for better or for worse? Examining NHS Reforms during times of economic crisis versus relative stability. Soc Policy Adm. 2011; 45: 488-505. http://dx.doi.o $\mathrm{rg} / 10.1111 / \mathrm{j} .1467-9515.2011 .00786 . \mathrm{x}$

[35] Lowden K, Hall S, Elliot D, et al. Employers' perceptions of the employability skills of new graduates. Glasgow, UK: Research commissioned by Edge Foundation University of Glasgow; 2011.

[36] Tomlinson M. Graduate employability and student attitudes and orientation to the labour market. Journal of Educational and Work 2007; 20(4): 285-304. http://dx.doi.org/10.1080/1363908 0701650164

[37] Leino-Loison K, Gien LT, Katajisto J, et al. Sense of coherence among unemployed nurses. J Adv Nurs. 2004; 48: 413-22. http: //dx.doi.org/10.1111/j.1365-2648.2004.03210.x

[38] Sun S, Song Z, Lim VKG. Dynamics of the job search process: Developing and testing a mediated moderating model. J Vocat Behav 2013; 98(5): 771-84. http://dx.doi.org/10.1037/a0033606 
[39] Lanaj K, Chang CH, Johnson RE. Regulatory focus and work-related outcomes: A meta-analysis. Psychol Bull. 2012; 138: 998-1034. http://dx.doi.org/10.1037/a0027723

[40] Vuoiri J, Silvonen J, Vinokur AD, et al. The Tyohon job search program in Finland: Benefit for unemployed with risk of depression or discouragement. J Occup Health Psychol. 2002; 7: 5-19. http://dx.doi.org/10.1037/1076-8998.7.1.5

[41] Brooks F, Nackerud L, Risler E. Evaluating of a job finding club for TANF recipients: Psychological impacts. Res Soc Work Pract. 2001; 11: 79-82. http://dx.doi.org/10.1177/10497315010110010 5
[42] Staines GL, Blankertz L, Magura S, et al. Efficacy of the customized employment supports (CES) model of vocational rehabilitation for unemployed methadone patients: preliminary results. Subst Use Misuse. 2004; 39(13-14): 2261-85. http://dx.doi.org/10.1081/J A-200034618

[43] Van Hooft EAJ, Noordzij G. The effect of orientation on job search and reemployment: A field experiment among unemployed job search. J Applied Psychol. 2009; 94: 1581-1590. http://dx.d oi.org/10.1037/a0017592

[44] Liu S, Huang JL, Wang M. Effectiveness of job search interventions: a meta-analytic review. Psychol Bull. 2014; 140(4): 1009-41. http://dx.doi.org/10.1037 